Artikel Riset

DOI : 10.33751/jf.v9i2.1609
Fitofarmaka Jurnal Ilmiah Farmasi

Vol.9, No.2, Desember 2019 : 103-108

p-ISSN : 2087-9164 e-ISSN : 2622-755X

\title{
PERBANDINGAN EFEKTIVITAS ANALGETIK EKSTRAK ETANOL DAN EKSTRAK AIR DAUN UNGU PADA MENCIT (Mus musculus L.)
}

\author{
Nhadira Nhestricia $^{1 *}$, Min Rahminiwati ${ }^{2}$, Erni Rustiani ${ }^{3}$, Fitri Dwiputri A ${ }^{4}$ \\ ${ }^{1,3,4}$ Program Studi Farmasi FMIPA Universitas Pakuan Bogor, \\ PO Box 452 Bogor 16143 \\ ${ }^{2}$ Fakultas Kedokteran Hewan, Institut Pertanian Bogor, Bogor ,16680 \\ West Java, Indonesia \\ *E-mail: nhadira.nhestricia@unpak.ac.id
}

Direvisi :28 Oktober 2019

Disetujui :30 November 2019

\begin{abstract}
ABSTRAK
Nyeri adalah perasaan sensorik atau emosional berupa perasaan tidak nyaman yang berhubungan dengan kerusakan dari suatu jaringan. Obat analgesik adalah obat yang memiliki aktivitas mengurangi rasa nyeri tanpa menghilangkan kesadaran. Penelitian ini bertujuan untuk membandingkan efek analgetik ekstrak etanol $96 \%$ dan ekstrak air, menentukan dosis ekstrak daun ungu yang paling efektif dan menentukan jangka waktu efek analgesik ekstrak obat pada mencit putih jantan (Mus musculus L.). Hewan coba digunakan sebanyak 20 ekor mencit putih jantan yang dibagi menjadi 5 kelompok perlakuan mulai P1 sampai P5. Hasil penelitian menunjukkan ekstrak daun ungu dengan pelarut etanol 96\% mempunyai efektivitas analgesik setara dengan kontrol positif. Sediaan paling paling efektif sebagai analgesik adalah Ekstrak Etanol Daun ungu $12 \mathrm{mg} / 20 \mathrm{~g}$ BB dengan nilai rata-rata lama mencit menahan rasa nyeri selama 16,08 detik yang diberikan pada kelompok P3, sedangkan kontrol positif Asetosal 1,82 $\mathrm{mg} / 20 \mathrm{~g} \mathrm{BB}$ memberikan waktu rata-rata 17,47 detik untuk menahan rasa sakit pada mencit.
\end{abstract}

Kata kunci: Ekstrak etanol Daun ungu, Ekstrak air daun ungu, Mus musculus, Analgesik.

\section{COMPARISSON OF ANALGESIC EFFECT BETWEEN ETHANOL AND AQUA EXTRACT OF Graptophyllum pictum LEAF IN Mus musculus}

\begin{abstract}
Pain is known as sensory or emotional uncomfortable associated with tissue damage. Analgesic comes as medicine to relief pain without lost consciousness. The aim of this study was to compare the effectiveness of analgesic between $96 \%$ ethanol extract and aqua extract of Graptophyllum pictum leaf in Mus musculus L. and to determine the period of analgesic effect of extract on mice. Twenty Mus musculus L. was divided into 5 treatment groups, P1 to P5 The results showed Graptophyllum pictum leaf extract with $96 \%$ ethanol solvent had analgesic effectiveness equivalent to positive control. The most effective preparation as analgesic was ethanol extract of purple leaves at dose of $12 \mathrm{mg} / 20 \mathrm{~g} \mathrm{BW}$ (P3 group) with 16.08 seconds duration time
\end{abstract}


for mice to hold pain while positive control of Asetosal $1.82 \mathrm{mg} / 20 \mathrm{~g} \mathrm{BW}$ gives an average time of 17.47 seconds to withstand pain in mice.

Keywords: Graptophyllum pictum ethanol extract, Graptophyllum pictum aqua extract, Mus musculus, Analgesic.

\section{PENDAHULUAN}

Nyeri menurut International Association Study of Pain (IASP), merupakan pengalaman sensorik atau emosional berupa perasaan tidak nyaman yang berhubungan dengan kerusakan dari suatu jaringan. Hasil stimulasi reseptor sensorik yang berupa gejala dari berbagai macam penyakit dan hampir dialami oleh setiap makhluk. Nyeri bertindak sebagai perangsang saraf-saraf sensorik, yang dapat menghasilkan reaksi ketidaknyamanan, dan distress atau menderita(Rospond, 2009). Nyeri dapat diobati dengan pemberian obat analgesik. Obat analgesik merupakan kelompok obat memiliki aktivitas mengurangi rasa nyeri tanpa menghilangkan kesadaran. Selain berasal dari senyawa kimia sintesis bisa juga berasal dari tumbuhan yang mengandung senyawa metabolit sekunder seperti flavonoid, dimana mekanisme kerjanya menghambat kerja enzim siklooksigenase (Suryanto, 2012). Penghambatan kerja enzim siklooksigenase terjadi dengan cara mengurangi produksi prostaglandin sehingga dapat mengurangi rasa nyeri (Gunawan dan Mulyani, 2004). Prostaglandin dapat menyebabkan terjadinya kontraksi dan relaksasi otot polos, pelebaran dan penyempitan pembuluh darah, mengontrol tekanan darah dan modulasi peradangan. Terdapat dua isodorm enzim COX yaitu COX-1 diseskresi secara terus menerus dalam sebagai besar jaringan dan dianggap melindungi mukosa lambung dan COX-2 diproduksi secara terus menerus di dalam otak dan ginjal serta dinduksi pada tempat yang mengalami inflamasi (Tjay \& Rahardja, 2008).

Salah satu tanaman yang bermanfaat sebagai analgesik yaitu daun ungu. Hasil penelitian Fauzi (2016) menyebutkan bahwa ekstrak etanol $96 \%$ dan ekstrak air daun ungu mengandung senyawa alkaloid, flavonoid dan saponin. Salah satu tanaman yang bermanfaat sebagai analgesik yaitu daun ungu. Sya'haya \& Nova (2016) juga mengemukakan mengenai efektivitas ekstrak daun ungu yang dapat digunakan untuk menanggulangi penyakit hemoroid karena isi kandungan daun ungu adalah alkaloid nontoksik, flavonoid, steroid, saponin, tanin yang berpotensi sebagai antiinflamasi dan juga sebagai analgesik. Menurut Madya Soekarno (2009) bahwa ekstrak etanol $96 \%$ daun ungu pada dosis $100 \mathrm{mg} / \mathrm{KgBB}$ dan $200 \mathrm{mg} / \mathrm{KgBB}$ dengan kontrol positif aspirin menggunakan metode induksi nyeri cara termik memiliki efek analgesik.

\section{TUJUAN}

Menentukan efek analgetik ekstrak etanol 96\%, menentukan dosis ekstrak etanol $96 \%$ yang paling efektif sebagai analgetik pada mencit (mus musculus L.), menentukan waktu pemberian ekstrak daun ungu sebagai analgetik pada mencit.

\section{METODE PENELITIAN}

Alat yang digunakan pada penelitian ini antara lain, Timbangan digital $\left(\mathrm{AND}^{\circledR}\right)$, timbangan analik $\left(\right.$ LabPro $\left.^{\circledR}\right)$, ayakan (Retsch $\mathrm{GmbH} \& \mathrm{Co}$, Jerman), termometer, Vacum dryer 
(Ogawa $\left.{ }^{\circledR}\right)$, oven $\left(\right.$ Memmert $\left.^{\circledR}\right), \quad$ tanur $\left(\right.$ Vulcan $\left.^{\circledR}\right)$, blender (philips $\left.{ }^{\circledR}\right)$, stopwatch, Hot Plate analgesic $\left(\mathrm{Ika}^{\circledR}\right)$, dan alat-alat gelas standar laboratorium lainnya.

Bahan-bahan yang digunakan terdiri dari Daun Ungu, Asetosal ${ }^{\circledR}$, Asam sulfat $2 \mathrm{~N}$, etanol 96\%, Na-CMC 1\% (China), Hewan percobaan Mencit (Mus musculus L) jantan, Makanan Mencit (Pellet BR-11), FeCl3 3\% (Merck), larutan $\mathrm{NaCl}$ (Merck), larutan gelatin $10 \%$, Pereaksi Dragendroff, Pereaksi Mayer, Serbuk magnesium.

\section{Pembuatan Serbuk Simplisia}

Sebanyak $3500 \mathrm{~g}$ daun ungu dikumpulkan dan dilakukan sortasi basah. Proses ini dilakukan agar terhindar dari pengotor yang menempel pada daun. Selanjutnya daun ungu dicuci dengan air bersih yang mengalir hingga bersih. Daun ungu dikeringkan dalam oven pada suhu $50^{\circ} \mathrm{C}$ selama kurang lebih 48 jam. Simplisia yang kering disortasi kering untuk memisahkan benda asing dari pengotor selama proses pengeringan. Tahap selanjutnya, simplisia dibuat serbuk menggunakan grinder dan diayak menggunakan ayakan 40 mesh. Simplisia yang diperoleh disimpan dalam wadah bersih dan tertutup rapat. Karakteristik simplisia meliputi pengujian susut pengeringa, kadar abu, uji fitokimia dan rendemen.

\section{Pembuatan Ekstrak}

Sebanyak 250 g serbuk daun ungu direndam ke dalam pelarut etanol $96 \%$ sebanyak 2,5 L. Pelarut tersebut dibagi menjadi 3 bagian, maserasi pertama sebanyak $1 \mathrm{~L}$, maserasi kedua sebanyak $750 \mathrm{~mL}$, dan maserasi ketiga sebanyak 750 mL. Tahap pertama perendamandilakukan dengan menggunakan pelarut sebanyak $1 \mathrm{~L}$ selama 6 jam pertama sambil sesekali di aduk, kemudian didiamkan selama 24 jam. Maserat dipisahkan dengan cara filtrasi. Filtrat yang di dapat didiamkan selama semalam (diendaptuangkan) untuk menghasilkan filtrat 1 , filtrat 2 , filtrat 3 dan hasil residu dibuang. Filtrat dikeringkan dengan Vacuum dryer pada suhu $60^{\circ} \mathrm{C}$ sampai menjadi ekstrak kering.

Karakteristik ekstrak meliputi pengujian kadar air, kadar abu, rendemen dan uji fitokimia.

\section{Persiapan Hewan Coba}

Sebanyak 20 ekor mencit (mus musculus) jantan yang sehat di kelompokan menjadi 5 kelompok terdiri dari 4 mencit dalam 1 kandang. Kemudian di aklimatisasi selama 7 hari untuk mengadaptasi hewan coba dengan lingkungan barunya, diberikan pakan BR512 dan minum secara ad libitum. Menghasilkan bobot badan mencit 20 30 g. Sebelum diberikan perlakuan, mencit ditimbang dan hitung $\mathrm{CV}$ (Coefficient variant) dengan syarat $\mathrm{CV}<$ $15 \%$ (Nasution,1992). Bila hasil CV telah memenuhi syarat kemudian diberikan perlakuan.

\section{Perlakuan Terhadap Hewan Coba}

Dilakukan uji analgetik awal dengan metode hot plate suhu $55^{\circ} \mathrm{C}$ hingga memberikan respon dalam waktu 3-6 detik. Hasil pengamatan menunjukan respon mengangkat kaki atau melompat. Mencit dikelompokkan menjadi 8 kelompok perlakuan secara acak. Masingmasing kelompok diberikan perlakuan sebagai berikut:

Kelompok P1: Ektrak Etanol Daun Ungu $4 \mathrm{mg} / 20 \mathrm{~g}$ BB mencit.

Kelompok P2: Ekstrak Etanol Daun Ungu $8 \mathrm{mg} / 20 \mathrm{~g}$ BB mencit.

Kelompok P3: Ekstrak Etanol Daun Ungu $12 \mathrm{mg} / 20$ gram BB mencit. 
Kelompok P4: Kontrol positif asetosal $1,82 \mathrm{mg} / 20 \mathrm{~g}$ BB mencit.

Kelompok P5: Kontrol negatif diberikan $\mathrm{Na}-\mathrm{CMC} 1 \%$.

Pengamatan dilakukan pada interval waktu ke- $0 ; 0,5 ; 1 ; 2 ; 3 ; 4 ; 5 ; 6 ; 7 ; 8$ jam. Data-data yang diperoleh dianalisis dengan analisis sidik ragam untuk rancangan acak kelompok (RAK) dengan menggunakan program SPSS versi 24.0.

\section{HASIL DAN PEMBAHASAN}

Daun ungu yang digunakan sebanyak 3,5 kg, setelah dilakukan proses pengeringan dan pengayakan diperoleh sebanyak 530 g. Rendemen simplisia yang diperoleh sebesar 15,14\%. Hasil pengujian susut pengeringan sebesar $7,94 \%$, memenuhi syarat yaitu tidak lebih dari 10\% (KemenKes RI,2010). Hasil pengujian kadar abu diperoleh sebesar $4,92 \%$, memenuhi syarat yaitu tidak lebih dar15,6\% (KemenKes RI, 2010).

Serbuk daun ungu dimaserasi menggunakan pelarut etanol $96 \%$ dan diinfudasi menggunakan pelarut air. Ekstrak kering etanol yang diperoleh 35,303 g dengan rendemen sebesar $14,12 \%$.

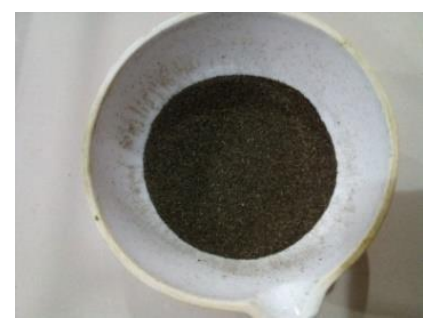

Gambar 1. Simplisia Daun Ungu

Hasil pemeriksaan organoleptik pada ekstrak etanol $96 \%$ daun ungu memiliki warna hijau, bau khas dan memiliki rasa pahit. Hasil pengujian kadar air ekstrak etanol diperoleh sebesar $0,921 \%$, memenuhi syarat yaitu tidak lebih dari 10\% (KemenKes RI, 2010). Hasil pengujian kadar abu ekstrak etanol diperoleh 4,034\%, menunjukkan kadar abu memenuhi syarat yaitu tidak lebih dari 15,6\% (KemenKes RI, 2010). Berdasarkan hasil uji fitokimia menunjukkan bahwa yang diperoleh serbuk simplisia, ekstrak etanol daun ungu (Graptophyllum pictum L.) yaitu positif mengandung senyawa alkaloid, flavonoid, saponin dan tanin.

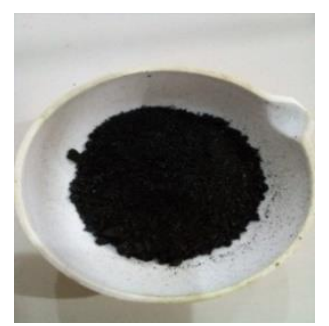

Gambar 2. Ekstrak Etanol Daun Ungu

Hasil Uji Efektivitas Analgesik Ekstrak Etanol 96\% dan Ekstrak Air Daun Ungu (Graptophyllum pictum L.) Pada Mencit (Mus musculus)

Hasil uji coba lulus dari Komite Etik Penggunaan Hewan Percobaan di Fakultas Matematika dan Ilmu Pengetahuan Alam Universitas Pakuan dengan No. 13/KEPHP-UNPAK/3-2019. Hewan coba dilakukan aklimatisasi \pm 7 hari , didapat nilai CV sebesar 6,372\%. Hasil tersebut dianggap homogen apabila nilai CV <15\% (Nasution, 1992).

Data respon tikus terhadap hot plate suhu $55^{\circ} \mathrm{C}$ dengan interval waktu jam ke- $0 ; 0,5 ; 1 ; 2 ; 3 ; 4 ; 5 ; 6 ; 7 ;$ dan 8 jam. Dapat dilihat pada Gambar 3. 


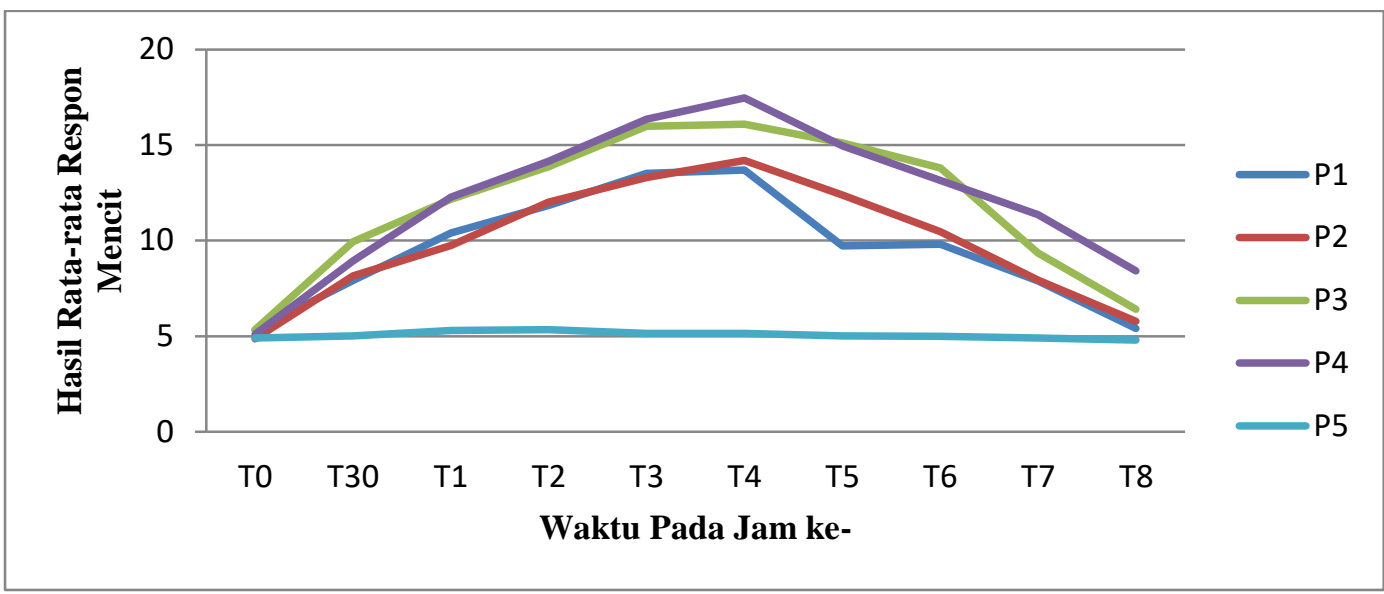

Gambar 3. Grafik Hasil Rata-rata Respon Analgesik Selama 8 Jam

Grafik pada Gambar 3. menunjukkan waktu paling lama menahan rasa nyeri pada kelompok kontrol negatif (CMC Na 1\%), kontrol positif (Asetsaol 1,82 $\mathrm{mg} / 20 \mathrm{~g} \quad \mathrm{BB}$ mencit), kelompok ekstrak etanol daun ungu. Terlihat bahwa kontrol negatif menunjukkan respon paling rendah terhadap menahan rasa nyeri. Sebaliknya kontrol positif menunjukkan respon paling lama terhadapat rasa nyeri, pada waktu T0,5 sudah memberika efektivitas analgesik hingga waktu tertinggi terjadi pada waktu T4. Pada kelompok ekstrak etanol dan ekstrak air dengan pemberian dosis yang sama, menunjukkan adanya efek analgetik terhadap hewan coba. Efek analgetik pada ekstrak etanol dengan dosis $12 \mathrm{mg} / 20 \mathrm{~g}$ BB mencit menunjukkan hasil yang mendekati dengan kontrol positif serta waktu tertinggi terjadi pada T4Berdasarkan grafik diatas, waktu terlama terjadi pada T4. Pada P3 (Ekstrak Etanol $12 \mathrm{mg} / 20 \mathrm{~g}$ BB Mencit) nilai waktu rata-rata yaitu 16,08 detik, P4 kontrol positif (Asetosal $1,82 \mathrm{mg} / 20 \mathrm{~g} \mathrm{BB}$ Mencit) yaitu 17,47 detik. Efek analgetik ekstrak maupun obat mengalami penurunan setelah memasuki jam ke-7 dan ke-8, karena pada waktu tersebut mengalami proses eliminasi.
Hasil data rata-rata waktu respon analgetik dianalisis menggunakan SPSS untuk melihat Uji ANOVA dan Uji Duncan untuk mengetahui adanya pengaruh pada setiap perlakuan. Hasil Analisis Post Hoc dengan menggunakan uji lanjut Duncan dapat disimpulkan bahwa perlakuan P5 Kontrol negatif (CMC $\mathrm{Na} \mathrm{1 \% )} \mathrm{berbeda} \mathrm{nyata} \mathrm{dengan}$ perlakuan lainnya. Perlakuan P3 (Ekstrak Etanol $12 \mathrm{mg} / 20 \mathrm{~g}$ BB Mencit) tidak berbeda nyata atau memiliki pengaruh yang sama dengan $\mathrm{P} 4$ kontrol positif Asetosal $1,82 \mathrm{mg} / / 20 \mathrm{~g}$ BB mencit) artinya efek analgesik yang ditimbulkan setara. Kandungan alkaloid dan flavonoid pada daun ungu mempunyai kandungan sebagai antiinflamasi dan analgetik, hal ini berkat kemampuan flavonoid yang mekanisme kerjanya menghambat kerja enzim siklooksigenase (Suryanto, 2012). Perbandingan antara perbedaan dosis pada perlakuan mempengaruhi hasil uji efektivitas analgesik. Dari hasil pengamatan diperoleh, bahwa ekstrak daun ungu menggunakan etanol 96\% memberikan efek analgesik setara dengan kontrol positif dari pada ekstrak air daun ungu. Hal ini diduga senyawa flavanoid lebih banyak ditarik menggunakan pelarut etanol $96 \%$. 


\section{KESIMPULAN}

Ekstrak daun ungu dengan pelarut etanol 96\% memiliki efek analgesik, ekstrak etanol $96 \%$ daun ungu pada dosis $12 \mathrm{mg} / 20 \mathrm{~g}$ BB mencit (P3) memiliki efek analgesik yang setara dengan kontrol positif Asetosal 1,82/20 g BB mencit (P4), waktu yang menunjukkan efektivitas analgesik setelah pemberian ekstrak etanol daun ungu $12 \mathrm{mg} / 20 \mathrm{~g} \mathrm{BB}$ adalah jam ke-4.

\section{REFERENSI}

Fauzi, D. 2016. Aktivitas Antibakteri Ekstrak Daun Ungu (Graptophyllum pictum L.) Terhadap Staphylococcus aureus dan Pseudomonas aeruginosa. Skripsi. Fakultas Teknobologi. Universitas Atma Jaya. Yogyakarta. Gunawan, D. \& Mulyani, S. 2004. Ilmu Meracik Obat (Farmakognosi). Penebar Swadaya. Yogyakarta.

Departemen Kesehatan R.I. 2010. Profil Kesehatan Indonesia Tahun 2009.
Kementerian Kesehatan Republik Indonesia. Jakarta.

Madya, S. 2009. Efek analgesik ekstrak etanol daun ungu (Graptophyllum pictum L) pada mencit galur Swiss Webster betina. Skripsi. Universitas Maranatha. Bandung.

Nasution. N. 1992. Metode Penelitian Naturalistik Kualitatif. Tarsito. Bandung.

Rospond, R. M. 2009. Pain assessment. Consult. Pharm. 8: 133-163.

Suryanto, E. 2012. Potensi ekstrak fenolik buah pisang goroho (Musa sp.) terhadap gula darah tikus putih (Ratus norvegicus), Chem. Prog. 6 (1): 6-10.

Sya'haya S \& Nova I. R. 2016. Pengaruh Pemberian Ekstrak Daun Ungu (Graptophyllum pictum Griff) Terhadap Penyembuhan Hemoroid. Majority. 5 (5): 155-160.

Tjay, T.H. \& Rahardja, K. 2007. Obatobat Penting. Edisi Keenam. P.T. Elex Media Komputindo. Jakarta. 